\title{
Forcing Culture of Witloof Chicory (Cichorium intybus L.) Using Fermentation Heat of Cow Manure
}

\author{
Takahiro KumANO ${ }^{1}$ and Hajime ARAKI $^{2}$ \\ 'Graduate School of Environmental Science, Hokkaido University, Sapporo, Hokkaido 060-0808, Japan \\ ${ }^{2}$ Field Science Center for Northern Biosphere, Hokkaido University, Sapporo, Hokkaido 060-0808, Japan
}

(Received January 20, 2016; Accepted June 14, 2016)

\begin{abstract}
This research investigated the feasibility of witloof chicory production with fermentation heat of cow's manure, in Hokkaido, during semi-cold and cold seasons. Forcing culture experiments were conducted in semi-cold season (once, April to May, 2013) and cold season (twice, March, 2014; March, 2015). In each experiment, cow compost produced through a solid-liquid separator (water content; 72.6\%) was used as heat sources. Temperature of outside air, indoor air, compost container, forcing chambers (soil and air) and heat exchangers were recorded. Through all experiments, compost temperature was maintained up to $30^{\circ} \mathrm{C}$, and it showed potential to be used as a heat source for chicory forcing culture. In semi-cold season, temperatures of forcing chambers $(6.3 \times 0.9 \times 0.65 \mathrm{~m})$ were maintained stably, and average air temperature of forcing chamber reached $17.2^{\circ} \mathrm{C}$ in average, and marketable etiolated heads (Chicon) were obtained after $22 \mathrm{~d}$. In cold season, air temperature of forcing chamber $(3.0 \times 0.9 \times 0.65 \mathrm{~m})$ was maintained stably $\left(10.6^{\circ} \mathrm{C}\right.$ in $2014,14.4^{\circ} \mathrm{C}$ in 2015 , in average), and marketable heads were obtained after 15 to $19 \mathrm{~d}$. The results indicated that witloof chicory forcing culture in semi-cold and cold seasons by using cow manure fermentation heat as heat sources is indeed possible.
\end{abstract}

Keywords : chicory, forcing culture, fermentation heat, heat recovery, manure composting

\section{INTRODUCTION}

With regard to the usage of livestock wastes, as a source of energy for agricultural production, many investigations have focused on the use of heat and electricity generation through biogas system (Weiland, 2010; Monteiro, 2011). However, studies which focused on the direct use of recovered heat from manure fermentation are limited (Mote and Griffis, 1982; Klejment and Rosinski, 2008). For indoor horticultural production, especially in cold regions such as Hokkaido, Japan, vast fossil fuels are still being consumed in the cold season. Over the past decades, increased attention has been given to search for alternative energy which has potential as a practical heat source for indoor horticultural production (Mitani, 1980; Kawamura et al., 2006; Fukui et al., 2009).

Through the composting process of livestock manures, it is well known that extracting heat from decomposition of organic matters is possible, and there are several studies which have aimed to use such techniques as heating systems for indoor agricultural production. To use fermentation heat directly as a heat source for horticultural production, two methods have been discussed mainly: 1) transferring heat from composting chambers to the cultivation place by heat exchanger to connect heat condensers buried in manure and heat radiators in the cultivation place (Seki and Komori, 1984), and 2) heat recovery by a vacuum-induced aeration system which forces air throughout the manure bed. The former method does not require a complicated mechanism and less initial investments, and also presents an advantage in efficiency of heat recovery with less thermal loss, while there are some disadvantages in workability when loading or turning of manure. We investigated the former method in present study. An advantage in the latter method is not only obtaining liquid fertilizer by acid-wash of vacuumed vapour from manure composting through ammonia scrubbers, but also the potential to realize both facility heating and $\mathrm{CO}_{2}$ fertilization by using ammonia-free vacuumed vapour, however, the high costs of initial investment is its disadvantage (Miyatake et al., 2009; Smith and Aber, 2014).

Thus far, the practical use of manure fermentation heat as a heat source for horticultural production has not been often, and it is reasonable to suppose that the main reason is the difficulty to realize efficient heat recovery from unstable heat sources. However, authors also assume that maybe several crops which do not require higher temperature for their growth can be grown by a heat source of limited capacity.

The cultivation of witloof chicory (Cichorium intybus L.) can be divided into two stages, namely root cultivation in open fields and forcing culture in dark containers. The forcing culture is usually conducted by high-density planting of roots within heat-insulated containers, so the required heat capacity is limited. The optimum temperature range for the forcing culture is around $15^{\circ} \mathrm{C}$ (Sasaki, 1990), relatively lower than that of typical indoor horticultural

Corresponding author: Hajime Araki, fax :81-11-706-3645, e-mail : araki@fsc.hokudai.ac.jp 
crops. Tight heads become loose and the marketable ratio of etiolated heads is normally decreased when the temperature during a forcing culture is out of the optimum range (12 to $18^{\circ} \mathrm{C}$ ) or unstable (Huyskes, 1961; Ryder, 1998).

Those unique characteristics gave the authors the idea that forcing culture of witloof chicory can be done by a limited heat source, such as manure fermentation as described above. The objective of the present study was to evaluate the feasibility of forcing culture of witloof chicory by using cow manure as a heat source, focusing on the direct heat recovery method by circulating antifreeze solution between composting chambers and forcing beds.

\section{MATERIALS AND METHODS}

Forcing culture experiments were conducted in Yubari City, Hokkaido, within indoor experimental facilities (E $141^{\circ} 58^{\prime} \mathrm{N} 43^{\circ} 3^{\prime}$ ). Experiments were done 3 times in total, one time in semi-cold season (April to May, 2013, $22 \mathrm{~d}$ ), and 2 times in cold season (March, 2014, 19 d, and March, 2015,15 d).
Dairy cow manure compost and heat exchange

For each experiment, dairy cow compost (water content; $72.6 \%, \mathrm{CN}$ ratio; 25$)$ was produced through a solidliquid separator (Yamashita et al., 2014). The applied amounts of compost were approximately $2 \mathrm{~m}^{3}$ for semi-cold season, and approximately $3 \mathrm{~m}^{3}$ for cold season. In semicold season, the size of the compost container was 2.92 $\mathrm{m}^{3}(1.8 \times 1.8 \times 0.9 \mathrm{~m})$, and the estimated total surface area of the heat exchanger $(0.7 \times 0.45 \times 0.03 \mathrm{~m})$ buried into the compost was $0.7 \mathrm{~m}^{2}$ (Fig. 1). In the cold seasons, the size of the compost container was $5.81 \mathrm{~m}^{3}(2.2 \times 2.2 \times 1.2 \mathrm{~m})$, and total surface area of the heat exchanger buried into the compost was $2.79 \mathrm{~m}^{2}$ (a spiral copper pipe, $2.2 \mathrm{~cm}$ diam., $40 \mathrm{~m}$ ) (Fig. 2). Obtained heat was supplied by circulating antifreeze solution through heat exchangers equipped in the compost chamber and polyethylene pipes (13 $\mathrm{mm}$ diam.), as heat radiators, which were installed in the forcing chambers (surface area of internal heat exchangers; $2.08 \mathrm{~m}^{2}$ in 2013, $1.00 \mathrm{~m}^{2}$ in 2014 and 2015). The antifreeze solution was circulated by water pump (UPS 25-60 180, GRUNDFOS Holding A/S, Denmark), and water flow was regulated by temperature indicator controller (R15, Azbil

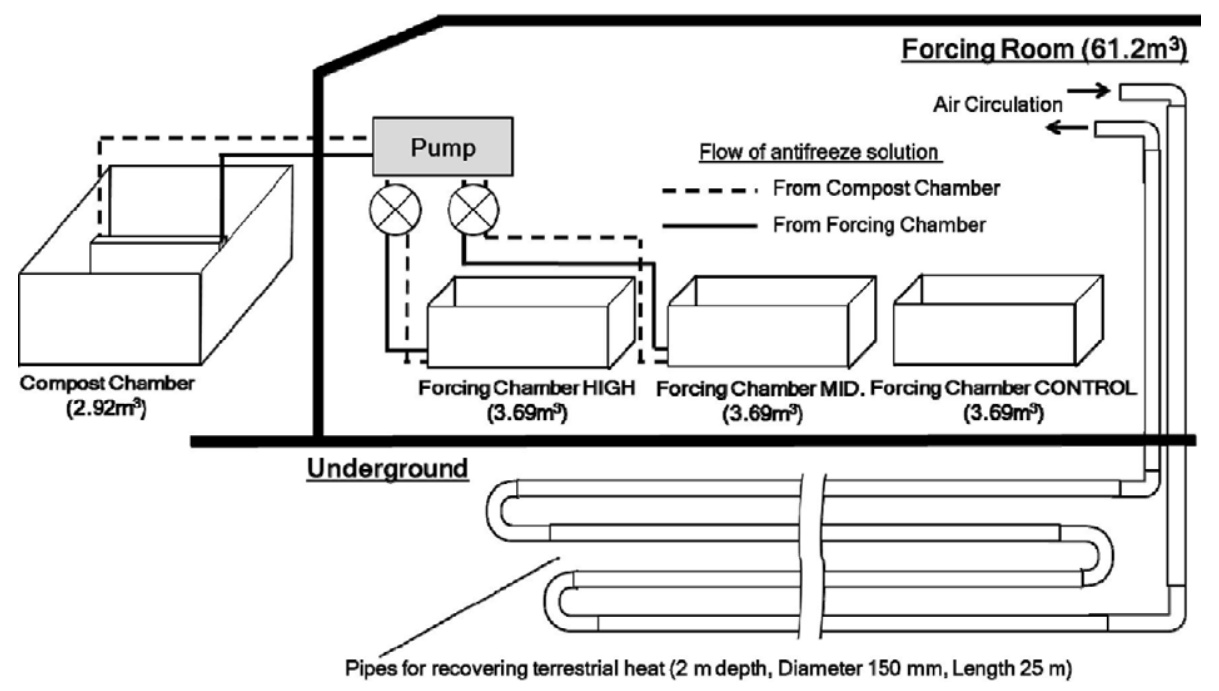

Fig. 1 Experimental facility used in semi-cold season, in 2013. The capacity of compost chamber was $2.92 \mathrm{~m}^{3}(1.8 \times 1.8 \times 0.9 \mathrm{~m})$. The capacity of forcing chambers were $3.69 \mathrm{~m}^{3}(6.3 \times 0.9 \times 0.65 \mathrm{~m})$, and those forcing chambers were installed in the forcing room $\left(61.2 \mathrm{~m}^{3} ; 12.6 \times 1.8 \times 2.7 \mathrm{~m}\right)$. The forcing room was connected with a terrestrial heat recovery system, and the air was circulated between the forcing room and underground pipes for recovering terrestrial heat by electric fan through the system.

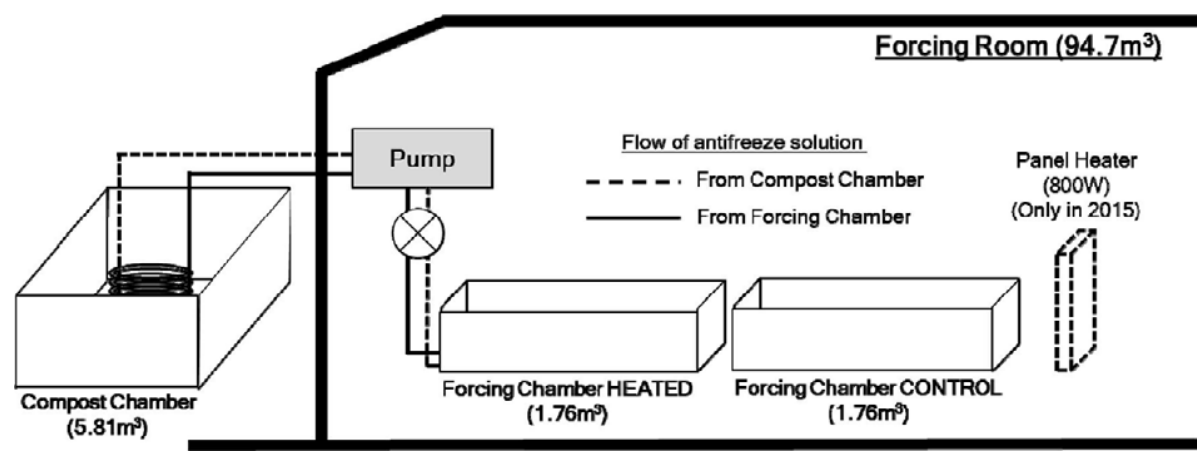

Fig. 2 Experimental facility in cold seasons, in 2014 and 2015 . The capacity of compost chamber was $5.81 \mathrm{~m}^{3}(2.2 \times 2.2 \times 1.2 \mathrm{~m})$. The capacity of forcing chambers was $1.76 \mathrm{~m}^{3}(3.0 \times 0.9 \times 0.65 \mathrm{~m})$, and those forcing chambers were installed into the forcing room $\left(94.7 \mathrm{~m}^{3} ; 12.6 \times 1.8 \times 2.7 \mathrm{~m}\right)$. An electric panel heater $(800 \mathrm{~W})$ was used to maintain the air temperature of forcing room higher than $0^{\circ} \mathrm{C}$, only in 2015 . 
Corp., Japan). Heat exchanger and heat radiators were connected by polyethylene pipes covered by heat insulators. In semi-cold season in 2013, manure turnings were executed $7 \mathrm{~d}, 12 \mathrm{~d}$ and $18 \mathrm{~d}$ after starting the forcing culture. In cold season in 2014, manure turnings were executed $6 \mathrm{~d}$ and 13 $\mathrm{d}$ after starting the forcing culture. In cold season in 2015 , manure turnings were executed $9 \mathrm{~d}$ after starting the forcing culture.

Semi-cold season examination, April in 2013

In the semi-cold season, three forcing chambers with same dimension $\left(3.69 \mathrm{~m}^{3} ; 6.3 \times 0.9 \times 0.65 \mathrm{~m}\right)$ with thermoinsulator and heat radiator were prepared in the room $(61.2$ $\left.\mathrm{m}^{3} ; 12.6 \times 1.8 \times 2.7 \mathrm{~m}\right)$ of agricultural experimental facility of local government of Yubari City, Hokkaido, and the inside temperature of forcing chambers was controlled manually at 3 temperatures, $19^{\circ} \mathrm{C}(\mathrm{HIGH}), 17^{\circ} \mathrm{C}$ (MID.) and non-heating (CONTROL), by regulating the amount of circulating antifreeze solution with a water valve. A terrestrial heat recovery system was used ( $2 \mathrm{~m}$ depth, $25 \mathrm{~m}$ length) to stabilize the air temperature of forcing room by air circulation between room and ducts buried underground by electric fan (Straight sirocco fan BFS-100SUC, Mitsubishi Electric Corp., Japan, air circulation speed; $1,000 \mathrm{~m}^{3} \mathrm{~h}^{-1}$ ) (Yamakawa et al., 2014).

Cold season examination, March in 2014 and 2015

In the cold season, two forcing chambers having the same dimension $\left(1.76 \mathrm{~m}^{3} ; 3 \times 0.9 \times 0.65 \mathrm{~m}\right.$, with thermoinsulator and heat radiator) were prepared in a room (94.7 $\mathrm{m}^{3} 11.6 \times 3.4 \times 2.4 \mathrm{~m}$ ) of the agricultural experimental facility of the local government of Yubari City, Hokkaido, and one was used for the treated (HEATED) and another for the non-treated (CONTROL). All forcing chambers were made with $12 \mathrm{~mm}$ thickness wooden boards (commercially available as concrete formwork), and the insides of the chambers were covered by heat insulator, $2.5 \mathrm{~cm}$ thickness extruded polystyrene foam sheet (Fig. 3). In 2015, an electric panel heater (Panel Heater Yumedanbo $880 \mathrm{H}(880$ W), RCS Corp., Japan) was used to maintain room air temperature above $0^{\circ} \mathrm{C}$.

Witloof chicory root production and planting in forcing culture

Witloof type cultivar 'Vintor' (Nunhems B.V., Nunhem, the Netherlands) was used for forcing culture. Chicory roots were produced at the Experimental Farm, Field Science Center for Northern Biosphere, Hokkaido University, Sapporo $\left(\mathrm{E} 141^{\circ} 20^{\prime} \mathrm{N} 43^{\circ} 4^{\prime}\right)$. In each year, the seeds were sown directly $\left(222,222\right.$ plants $\left.h^{-1}\right)$ into open fields in mid-July, and roots were harvested around $145 \mathrm{~d}$ after sowing. After washing of harvested roots by tap water, roots were sorted and cut into $20 \mathrm{~cm}$ lengths (from root shoulder to the bottom end), and stored in refrigerator, air temperature 0.2 to $0.8^{\circ} \mathrm{C}$, relative humidity $100 \%$, until the start of forcing culture.

In each experiment, roots were transplanted into plastic containers $(57.5 \times 41.5 \times 19.0 \mathrm{~cm})$ which were filled with medium for nursery production; Takii Tanemaki Baido (Takii Co., Ltd., Japan), and plant density was 120.0 plants $\mathrm{m}^{-2}$. Roots were grown under dark condition, and irrigation was done periodically. Total 15 roots were planted for each treatment in semi-cold season. Total 60 roots were planted for treated plot, and 10 roots were planted for CONTROL in cold season, in 2014. Total 60 roots were planted for treated plot, and 20 roots were planted for CONTROL in cold season, in 2015.

Measurement of temperature and evaluation of calorific value supplied from compost

Temperatures of outside, forcing room, hot water inlet and outlet, inside forcing chambers (air and soil) and manure were recorded in a data logger (midi logger GL820, Graphtec Corp., Japan) using thermocouple wires every hour during forcing cultivation. As to the estimation of calorific value supplied from manure composting heat to forcing chambers, the temperature difference of circulated antifreeze solution between the inlet and outlet of the forcing chamber was measured, and the amount of fluid flow per minute was recorded by liquid flow meter (Liquid flowmeter LD20-PATAAA-RC, HORIBA, Japan).

Growth characteristics of etiolated heads emerging in forcing culture

Fresh weight (FW) (before and after trimming), height, diameter and flower stalk length of etiolated heads were measured when those heads were harvested in each experiment, $22 \mathrm{~d}, 19 \mathrm{~d}$ and $15 \mathrm{~d}$ after starting the forcing culture, in semi-cold season in 2013, in cold-season in 2014, and cold-season in 2015, respectively. Relative core ratio was calculated as core length/etiolated head length $\times 100$. The growth of etiolated heads emerged was measured and statistically analysed and the significant differences in mean values were calculated using Tukey-HSD test and Welch's $t$ test.

\section{RESULTS}

Semi-cold season (April to May, 2013)

The air temperature of the forcing room was kept over $0^{\circ} \mathrm{C}$ during the forcing cultivation even though the mini-

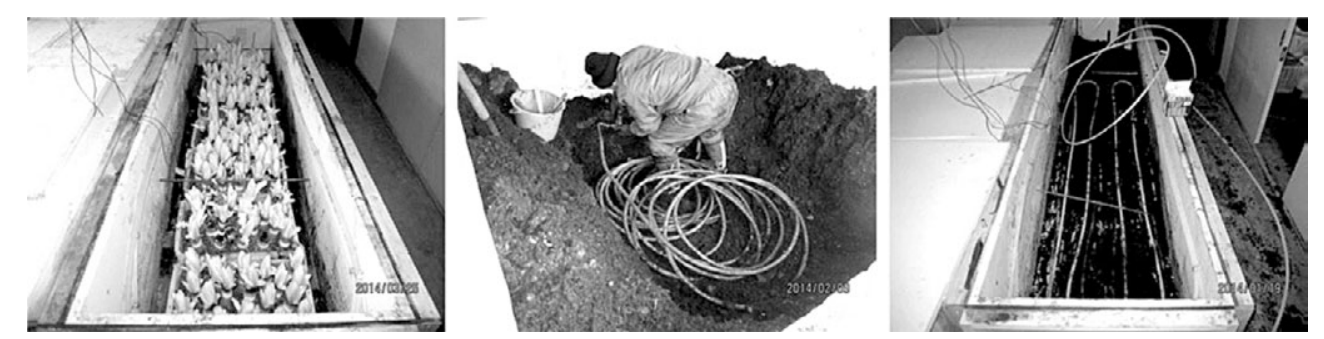

Fig. 3 Forcing chamber (Left), heat condenser (copper pipe) in composting chamber (Center) and heat radiator (polyethylene pine) in forcing chamber (Right). 
mum outside air temperature was $-3.3{ }^{\circ} \mathrm{C}$ because of the terrestrial heat exchange system (Fig. 4). Nevertheless, the outside air temperature averaged $4.3^{\circ} \mathrm{C}$, and manure temperature was kept over $40^{\circ} \mathrm{C}$ from $2 \mathrm{~d}$ after starting the forcing culture. The manure temperature tended to increase after 2 to $3 \mathrm{~d}$ of each turning (27 April, 2 May and 8 May, 2013). During the forcing period, from 20 April to 12 May, 2013, the air temperature of the inside forcing chamber was kept stably $\left(15.2^{\circ} \mathrm{C}\right.$ at the MID, $17.2^{\circ} \mathrm{C}$ at the $\mathrm{HIGH}$, on average), especially from $7 \mathrm{~d}$ (27 April) to $18 \mathrm{~d}$ (7 May) after the start of forcing culture. The average $\mathrm{FW}$ of trimmed etiolated head showed over $210 \mathrm{~g}$ at the HIGH, and $170 \mathrm{~g}$ at the MID; those were significantly higher than CONTROL at the 5\% level (Table 1). In HIGH and MID treatment, the FW ratio (after/ before trimming) was at the same level of CONTROL, however, the core ratios in them were significantly higher than CONTROL at the $5 \%$ level. The temperature of forcing chambers decreased from 8 May until the end of forcing cultivation due to malfunction of a pump used for circulation of antifreeze liquid.

Cold season (March, 2014)

The average air temperature of the forcing room was $0.9^{\circ} \mathrm{C}$ during the forcing cultivation while average outside air temperature was $-4.2^{\circ} \mathrm{C}$ in March 2014 (Fig. 5). Manure temperature was kept over $35^{\circ} \mathrm{C}$ almost through the forcing period, $38.3^{\circ} \mathrm{C}$ on average. The same trend in the previous experiment in 2013 was observed in manure temperature, which always increased after 1 to $2 \mathrm{~d}$ from turning (8 March and 15 March, 2014). During the forcing

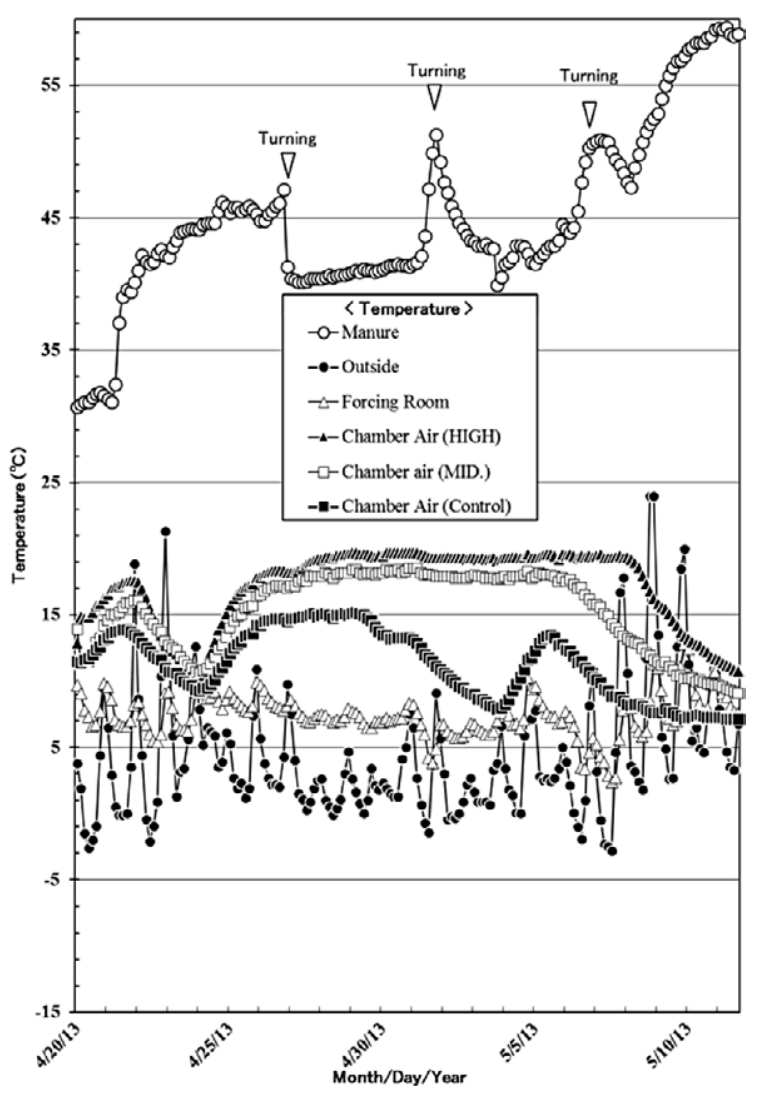

Fig. 4 Transition of air temperature during forcing culture (20 April to 12 May, 2013). period, from 2 to 21 March, 2014, the air temperature inside the forcing chamber of HEATED was kept stably at $10.6^{\circ} \mathrm{C}$ on average. Air temperature in CONTROL averaged $0.5^{\circ} \mathrm{C}$ almost the same level as that in the forcing room.

The average FW of trimmed etiolated head was around $100 \mathrm{~g}$ in HEATED, and there was a significant difference between CONTROL and HEATED at $1 \%$ level (Table 2). The size of the etiolated head in HEATED was relatively smaller than a commercial one, however, the head height in HEATED was significantly higher than CONTROL at $1 \%$ level. The average core ratio in HEATED was lower than 0.2 , and the FW ratio of etiolated head (after/ before trimming) reached almost 90\%, significantly higher than CONTROL at $1 \%$ level.

\section{Cold season (March, 2015)}

The average air temperature in the forcing room was $6.3^{\circ} \mathrm{C}$ during the forcing cultivation while the average outside air temperature was $0.4^{\circ} \mathrm{C}$ (Fig. 6). From $5 \mathrm{~d}$ after starting the forcing culture, manure temperature was kept over $30^{\circ} \mathrm{C}$, and averaged $27.9^{\circ} \mathrm{C}$. During the forcing period, from 6 to 21 March, 2015, the air temperature inside the forcing chamber of HEATED was kept at $14.4^{\circ} \mathrm{C}$ on average, while that in CONTROL averaged $5.3^{\circ} \mathrm{C}$.

The volume of the forcing room was $94.7 \mathrm{~m}^{3}(11.6 \times$ $3.4 \times 2.4 \mathrm{~m}$ ). The air temperature in the forcing room was kept between 3.2 to $10.7^{\circ} \mathrm{C}$ by the small electric panel heater $(880 \mathrm{~W}), 2.1^{\circ} \mathrm{C}$ in average higher compared with the other room which does not have any heating systems in

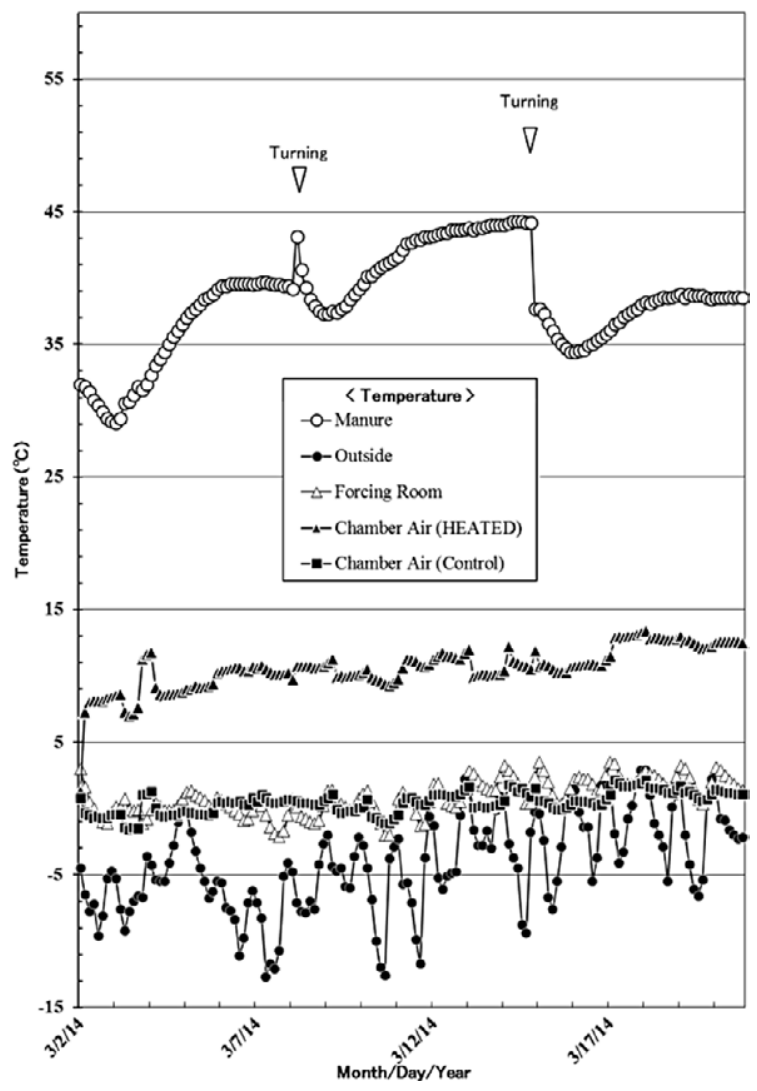

Fig. 5 Transition of air temperature during forcing culture (2 to 21 March, 2014). 


\section{SUSTAINABLE CHICORY CULTURE}

Table 1 Effect of forcing temperature on etiolated head yield and quality in semi-cold season, 20 April to 12 May, 2013.

\begin{tabular}{|c|c|c|c|c|c|c|c|c|c|}
\hline \multirow{2}{*}{$\begin{array}{c}\text { Expected } \\
\text { Temperature }\end{array}$} & \multicolumn{2}{|c|}{$\begin{array}{c}\text { Average } \\
\text { Temperature }^{y}\end{array}$} & \multirow{2}{*}{$\begin{array}{c}\text { Before } \\
\text { Trimming } \\
\begin{array}{c}\text { Fresh Weight } \\
\text { (g/plant) }\end{array}\end{array}$} & \multicolumn{4}{|c|}{ After Trimming ${ }^{2}$} & \multicolumn{2}{|c|}{ Chicon Quality Index } \\
\hline & Air $\left({ }^{\circ} \mathrm{C}\right)$ & Soil $\left({ }^{\circ} \mathrm{C}\right)$ & & $\begin{array}{c}\text { Fresh Weight } \\
\text { (g/plant) }\end{array}$ & Height $(\mathrm{cm})$ & $\begin{array}{l}\text { Diameter } \\
(\mathrm{cm})\end{array}$ & $\begin{array}{l}\text { Core Length } \\
\quad(\mathrm{cm})\end{array}$ & $\begin{array}{c}\text { FW Ratio } \\
\text { (After/Before } \\
\text { Trimming) }\end{array}$ & $\begin{array}{c}\text { Core Ratio } \\
\text { (Length/ } \\
\text { Height) }\end{array}$ \\
\hline $\begin{array}{c}\text { CONTROL } \\
\text { (Non-Heating) }\end{array}$ & 11.3 & 10.0 & $137.9 \pm 7.0 \mathrm{c}^{\mathrm{x}}$ & $88.4 \pm 5.6 \mathrm{c}$ & $11.5 \pm 0.34 b$ & $5.5 \pm 0.20 \mathrm{~b}$ & $2.7 \pm 0.18 \mathrm{c}$ & $0.65 \pm 0.03 \mathrm{a}$ & $0.24 \pm 0.01 \mathrm{c}$ \\
\hline $\operatorname{MID}\left(17^{\circ} \mathrm{C}\right)$ & 15.2 & 14.9 & $248.9 \pm 8.2 b$ & $169.8 \pm 4.8 \mathrm{~b}$ & $13.5 \pm 0.25 \mathrm{a}$ & $8.3 \pm 0.21 \mathrm{a}$ & $6.1 \pm 0.41 b$ & $0.69 \pm 0.01 \mathrm{a}$ & $0.45 \pm 0.03 \mathrm{~b}$ \\
\hline $\mathrm{HIGH}\left(19^{\circ} \mathrm{C}\right)$ & 17.2 & 15.5 & $336.7 \pm 19.4 \mathrm{a}$ & $211.6 \pm 17.5 \mathrm{a}$ & $13.8 \pm 0.77 \mathrm{a}$ & $9.0 \pm 0.50 \mathrm{a}$ & $7.9 \pm 0.55 \mathrm{a}$ & $0.64 \pm 0.06 \mathrm{a}$ & $0.59 \pm 0.06 \mathrm{a}$ \\
\hline Tukey-HSD test & & & $* *$ & $*$ & $*$ & $* *$ & $* *$ & ns & $*$ \\
\hline
\end{tabular}

${ }^{2}$ Roots were trimmed into $20 \mathrm{~cm}$ lengths (shoulder to the bottom end), and sorted ( $452.3 \mathrm{~g}$ fresh weight in average).

${ }^{y}$ Period; 20 April, 2013-12 May, 2013 (22 d).

${ }^{x} n=15$, mean \pm SE, The numbers followed by the same letter within a column are not significantly different according to the Tukey-HSD test.

${ }^{w} \mathrm{~ns}, * *$ and $*$ indicate not significant, significant at $P<0.01$ and $P<0.05$, respectively.

Table 2 Effect of forcing temperature on etiolated head yield and quality in cold season, 2 March to 21 March, 2014.

\begin{tabular}{|c|c|c|c|c|c|c|c|c|c|}
\hline \multirow[b]{2}{*}{ Treatment } & \multicolumn{2}{|c|}{$\begin{array}{c}\text { Average } \\
\text { Temperature }^{y}\end{array}$} & \multirow{2}{*}{$\begin{array}{c}\text { Before } \\
\text { Trimming } \\
\begin{array}{c}\text { Fresh Weight } \\
\text { (g/plant) }\end{array}\end{array}$} & \multicolumn{4}{|c|}{ After Trimming ${ }^{2}$} & \multicolumn{2}{|c|}{ Chicon Quality Index } \\
\hline & Air $\left({ }^{\circ} \mathrm{C}\right)$ & Soil $\left({ }^{\circ} \mathrm{C}\right)$ & & $\begin{array}{l}\text { Fresh Weight } \\
\text { (g/plant) }\end{array}$ & Height $(\mathrm{cm})$ & $\begin{array}{l}\text { Diameter } \\
(\mathrm{cm})\end{array}$ & $\begin{array}{l}\text { Core Length } \\
(\mathrm{cm})\end{array}$ & $\begin{array}{c}\text { FW Ratio } \\
\text { (After/Before } \\
\text { Trimming) }\end{array}$ & $\begin{array}{c}\text { Core Ratio } \\
\text { (Length/ } \\
\text { Height) }\end{array}$ \\
\hline $\begin{array}{c}\text { Control } \\
\text { (Non-Heating) }\end{array}$ & 0.5 & -0.5 & $7.4 \pm 1.0^{x}$ & $4.0 \pm 0.4$ & $6.3 \pm 0.3$ & N/A ${ }^{w}$ & N/A ${ }^{w}$ & $0.55 \pm 0.03$ & N/Aw \\
\hline $\begin{array}{l}\text { Heated } \\
t \text {-test }{ }^{\mu}\end{array}$ & 10.6 & 11.0 & $\begin{array}{c}117.1 \pm 2.5^{\mathrm{v}} \\
* *\end{array}$ & $\begin{array}{c}103.9 \pm 2.2 \\
* *\end{array}$ & $\begin{array}{c}14.0 \pm 0.1 \\
* *\end{array}$ & $\begin{array}{c}4.9 \pm 0.1 \\
-\end{array}$ & $\begin{array}{c}2.6 \pm 0.1 \\
-\end{array}$ & $\begin{array}{c}0.89 \pm 0.00 \\
* *\end{array}$ & $\begin{array}{c}0.19 \pm 0.00 \\
-\end{array}$ \\
\hline
\end{tabular}

${ }^{\mathrm{z}}$ Roots were trimmed into $20 \mathrm{~cm}$ lengths (shoulder to the bottom end), and sorted (208.2 $\pm 4.0 \mathrm{~g}$ fresh weight).

${ }^{y}$ Period; 2 Mar., 2014-21 Mar., 2014 (19 d).

${ }^{x} n=10$, mean $\pm \mathrm{SE}$

${ }^{w}$ Data were not obtained because of poor growth of chicons.

${ }^{v} n=60$, mean $\pm \mathrm{SE}$

"ns, ** and * indicate not significant, significant at $P<0.01$ and $P<0.05$, respectively.

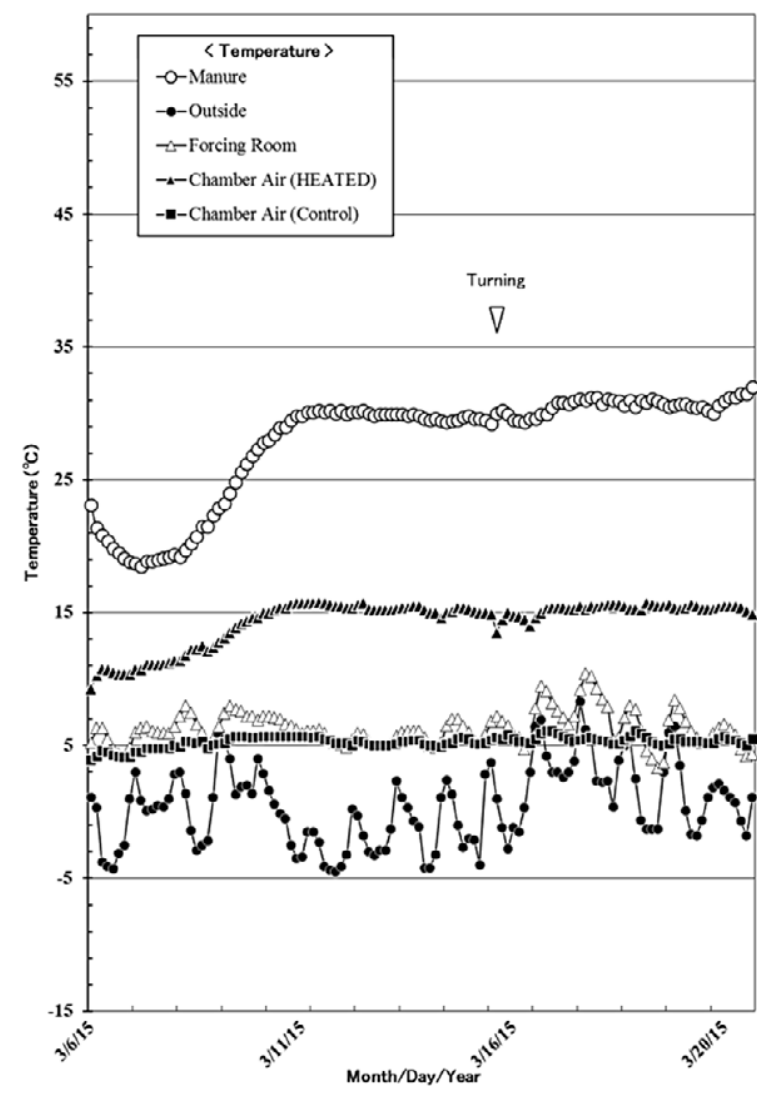

Fig. 6 Transition of air temperature during forcing culture (6 to 21 March, 2015). the experimental facility throughout the cultivation period. Manure was turned only once during the forcing culture, 9 d after starting (15 March, 2015); however, no large increase was observed after turning. Based on recorded data of the temperature difference between inlet and outlet of anti-freezing liquid and flow rate, the heat energy introduced into the heat chamber per hour was evaluated 134.7 $\mathrm{kJ} \mathrm{h}^{-1}$.

After removing the outer leaves, the average FW of etiolated head in HEATED was $147.3 \mathrm{~g}$, significantly larger than that in CONTROL at $1 \%$ level (Table 3). Both height and diameter of head in HEATED were significantly higher than those of CONTROL at $1 \%$ level. The average core ratio in HEATED was kept lower than 0.4. The FW ratio (after/ before trimming) in HEATED was significantly higher than CONTROL. These results showed that the temperature during forcing culture was controlled with enough stability to maintain the practical level of etiolated head quality (Fig. 7).

\section{DISCUSSION}

Factors obtained marketable head from the forcing culture of chicory

Marketable etiolated heads of chicory were obtained in the examination semi-cold season (May in 2013) and cold season (March in 2015) and not done in cold season (March in 2014). In the semi-cold season examination (2013), unless outside temperature was around $0-5^{\circ} \mathrm{C}$, the temperature of the forcing room was maintained around 

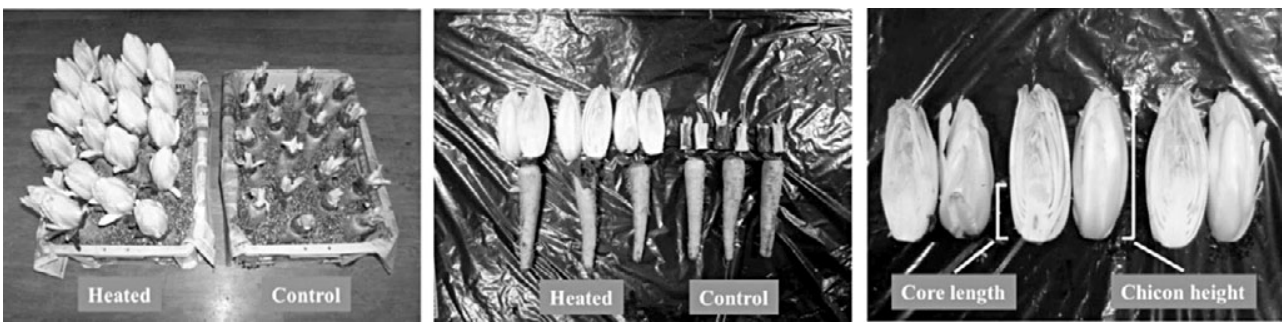

Fig. 7 Forcing culture within plastic container (Left), heads and roots when harvested (15 d after starting forcing culture) (Center) and definition of head height and core length (Right).

Table 3 Effect of forcing temperature on etiolated head yield and quality in cold season, 6 March to 21 March, 2015.

\begin{tabular}{|c|c|c|c|c|c|c|c|c|c|}
\hline \multirow[b]{2}{*}{ Treatment } & \multicolumn{2}{|c|}{$\begin{array}{c}\text { Average } \\
\text { Temperature }^{y}\end{array}$} & \multirow{2}{*}{$\begin{array}{c}\text { Before } \\
\text { Trimming } \\
\begin{array}{c}\text { Fresh Weight } \\
\text { (g/plant })\end{array}\end{array}$} & \multicolumn{4}{|c|}{ After Trimming ${ }^{2}$} & \multicolumn{2}{|c|}{ Chicon Quality Index } \\
\hline & Air $\left({ }^{\circ} \mathrm{C}\right)$ & Soil $\left({ }^{\circ} \mathrm{C}\right)$ & & $\begin{array}{c}\text { Fresh Weight } \\
\text { (g/plant) }\end{array}$ & Height $(\mathrm{cm})$ & $\begin{array}{l}\text { Diameter } \\
(\mathrm{cm})\end{array}$ & $\begin{array}{l}\text { Core Length } \\
(\mathrm{cm})\end{array}$ & $\begin{array}{c}\text { FW Ratio } \\
\text { (After/Before } \\
\text { Trimming) }\end{array}$ & $\begin{array}{c}\text { Core Ratio } \\
\text { (Length/ } \\
\text { Height) }\end{array}$ \\
\hline $\begin{array}{c}\text { CONTROL } \\
\text { (Non-Heating) }\end{array}$ & 5.3 & 4.8 & $27.3 \pm 1.3^{x}$ & $11.6 \pm 0.4$ & $7.6 \pm 0.2$ & $2.1 \pm 0.0$ & $0.9 \pm 0.1$ & $0.44 \pm 0.01$ & $0.12 \pm 0.01$ \\
\hline $\begin{array}{l}\text { Heated } \\
t \text { test }^{\mathrm{v}}\end{array}$ & 14.4 & 14.7 & $\begin{array}{c}163.0 \pm 1.9^{w} \\
* *\end{array}$ & $\begin{array}{c}147.3 \pm 1.7 \\
* *\end{array}$ & $\begin{array}{l}14.3 \pm 0.1 \\
* *\end{array}$ & $\begin{array}{c}5.9 \pm 0.0 \\
* *\end{array}$ & $\begin{array}{c}5.3 \pm 0.1 \\
* *\end{array}$ & $\begin{array}{c}0.90 \pm 0.00 \\
* *\end{array}$ & $\begin{array}{c}0.37 \pm 0.00 \\
* *\end{array}$ \\
\hline
\end{tabular}

${ }^{2}$ Roots were trimmed into $20 \mathrm{~cm}$ lengths (shoulder to the bottom end), and sorted between 4.1 to $4.4 \mathrm{~cm}$ diameter $(195.5 \pm 1.1 \mathrm{~g}$ fresh weight).

${ }^{y}$ Period; 6 Mar., 2015-21 Mar., 2015 ( 15 d).

${ }^{x} n=20$, mean $\pm \mathrm{SE}$

${ }^{\mathrm{w}} n=60$, mean $\pm \mathrm{SE}$

${ }^{v} \mathrm{~ns}, * *$ and $*$ indicate not significant, significant at $P<0.01$ and $P<0.05$, respectively.

$5^{\circ} \mathrm{C}$ by a terrestrial heat recovery system which circulates air between the forcing room and underground pipes at $2 \mathrm{~m}$ depth. In addition, air temperature in the forcing chamber was maintained at $17.2^{\circ} \mathrm{C}(\mathrm{HIGH})$ and $15.2^{\circ} \mathrm{C}$ (MID), in average, by supplying the exchanged heat from fermented manure compost, over $50^{\circ} \mathrm{C}$. On the other hand, in the cold season examination (2014), the temperature inside the compost was around $40^{\circ} \mathrm{C}$, close to the level in 2013 , while air temperature inside the forcing chamber was less than $10^{\circ} \mathrm{C}$ unless exchanged heat from compost was inserted into the forcing chamber. The difference in environmental factor between the examination in semi-cold (2013) and cold season (2014) was the temperature in the forcing room. Heat insulator boards, $20 \mathrm{~mm}$ in thickness, were attached at bottom, top and side of the forcing chamber; however, it was supposed that the compost heat was not enough to elevate the air temperature to $15^{\circ} \mathrm{C}$ inside the forcing chamber. A panel heater was set for warming the forcing room in the cold season examination in 2015 and the temperature in forcing room increased to around $5^{\circ} \mathrm{C}$. Though the temperature inside the compost was around $30^{\circ} \mathrm{C}$ in 2015 , less than that in previous years, the air temperature inside the forcing chamber reached $15^{\circ} \mathrm{C}$. Those results indicate that maintaining room air temperature above $0^{\circ} \mathrm{C}$ enhances the controllability of air temperature in the forcing chamber for the growth of etiolated heads, and for this purpose, a terrestrial heat recovery system can be considered one of the practical options.

Temperature increase in manure composting

Miyatake et al. (2009) reported that manure temperature during composting can be increased and stabilized by turning, and the obtained heat energy increased more than 1.5 times, 141 to $216 \mathrm{~J} \mathrm{~s}^{-1} \mathrm{~m}^{-3}$, when the frequency of turning increased, from once a week to twice a week. Through the present experiments, manure was turned every 6 to $9 \mathrm{~d}$ in 2013 and 2014, and the manure temperature increased after 3 to $4 \mathrm{~d}$ from turning. These facts indicated the importance of turning manure to maintain keep high its temperature during the composting process.

Volume of compost required per heating of forcing chamber

The volume ratio of composting manure used $\left(3.0 \mathrm{~m}^{3}\right)$ to the forcing chamber $\left(1.76 \mathrm{~m}^{3}\right)$ was 1.70 in 2014 and 2015 , and marketable etiolated heads of witloof chicory with sufficient quality were obtained by using the compost heat. From what has been discussed above, there was no report on the relationship between the compost volume and the chamber volume, and it seems reasonable to conclude that the required volume of composting manure per volume of forcing chambers of witloof chicory can be estimated as 1.70 at least.

Estimated energy produced by cow manure and exchanged with forcing chambers

According to the study by Seki and Komori (1984) which was conducted with a small heat insulated compost chamber $\left(0.71 \mathrm{~m}^{3}\right)$, recoverable heat energy from composting manure (mixture of cow's manure, poultry manure, rice bran and sawdust) was estimated to be around $836.8 \mathrm{~kJ}$ $\mathrm{m}^{-3} \mathrm{~h}^{-1}$. Miyatake et al. (2009) also reported that, through a vacuum-induced aeration system, the estimated recoverable heat energy from composting of manure (mixture of milk cow manure and dried rice straw) was $216 \mathrm{~J} \mathrm{~s}^{-1} \mathrm{~m}^{-3}$. Based on the result of our experiment in 2015, in this study, the estimated transferred heat energy into the forcing chamber per hour was calculated as $134.7 \mathrm{~kJ} \mathrm{~h}^{-1}$, and the estimated produced heat from $3 \mathrm{~m}^{3}$ cow manure composting 


\section{SUSTAINABLE CHICORY CULTURE}

was calculated as 648.0 to $697.8 \mathrm{~J} \mathrm{~s}^{-1}$. The heat exchange efficiency of this system is between 5.4 to $5.8 \%$.

\section{CONCLUSION}

The witloof chicory's optimum temperature range for forcing is relatively cooler and cultivation period is shorter, compared to other indoor horticultural crops. Through this study, it became clear that the witloof chicory forcing cultivation can be done with low heat energy, such as fermentation heat of livestock manure, in small enclosed spaces. The results also indicate that the temperature which is required for witloof chicory forcing culture with small heatinsulated chambers can be managed by low heat energy from the cow manure composting process. Besides, keeping the temperature of the forcing room at more than $5^{\circ} \mathrm{C}$ is preferable for warming the temperature inside the forcing chamber for the emergence of etiolated head. Further research on commercial-scale demonstration experiments would clarify the practical feasibility composting manure as a heat source for witloof chicory forcing production.

\section{ACKNOWLEDGEMENTS}

We wish to thank Mr. T. Kawai and Mr. H. Nakano, technicians of the Field Science Center for Northern Biosphere, Hokkaido University, Mr. T. Yokota, Yokota Setsubi Co., Ltd. and Ms. R. Yamakawa, Graduate School of Environmental Science, Hokkaido University, for their generous technical assistance in crop cultivation and installation of the forcing culture system.

\section{REFERENCES}

Fukui, Y., Kubai, K., Nakamura, M. 2009. A survey of farmers' views on energy conservation and alternative energy sources for greenhouse heating and the conditions required for introduction of these technologies. (in Japanese text with English summary) Bull. Kochi Agric. Res. Cent. 18: 49-58.

Huyskes, J. A. 1962. Cold requirements of witloof chicory varieties (Cichorium intybus L.) as a yield-determining factor.
Euphytica 11: 36-41.

Kawamura, A., Akisawa, A., Kashiwagi, T. 2006. Application problem of biomass combustion in Greenhouses for crop production. (in Japanese text with English summary) J. High Temp. Soc. 33: 14-20.

Klejment, E., Rosinski, M. 2008. Testing of thermal properties of compost from municipal waste with a view to using it as a renewable, low temperature heat source. Bioresour. Technol. 99: $8850-8855$

Mitani, H. 1980. The actual examples of district heating or cooling, power generation, and heat supply on refuse incinerating plant at Sapporo City. (in Japanese) J. Environ. Conserv. Eng. 9: 404-411.

Miyatake, F., Abe, Y., Honda, Y., Iwabuchi, K. 2009. Effect of turning frequency on heat recovery and emitted carbon dioxide concentration in dairy manure composting with vacuuminduced aeration system. (in Japanese text with English summary) J. Soc. Agric. Struc. Jpn. 3: 295-302.

Monteiro, E., Mantha, V., Rouboa, A. 2011. Prospective application of farm cattle manure for bioenergy production in Portugal. Renew. Energ. 36: 627-631.

Mote, C. R., Griffis, C. L. 1982. Heat production by composting organic matter. Agric. Waste 4: 65-73.

Ryder, E. J. 1998. Lettuce, endive and chicory. CAB International, London, p 47-49.

Sasaki, H. 1990. Cultivation and forcing of chicory plants (Cichorium intybus L.). J. Hokkaido Univ. Edu. 40: 133-142.

Seki, H., Komori, T. 1984. A proposal and trial of heat extraction from a compost bed by water flowing through the pipe buried in the bed. (in Japanese text with English summary) J. Agric. Meteorol. 40: 219-228.

Smith, M., Aber, J. 2014. Heat recovery from compost. BioCycle 55: 26-29.

Weiland, P. 2010. Biogas production: current state and perspectives. Appl. Microbiol. Biotechnol. 85: 849-860.

Yamakawa, R., Kumano, T., Araki, H., Yokota, T. 2014 Chicory (Cichorium intybus) production of using local snow and terrestrial heat energy in mid-summer, Japan. Acta Hortic. 1037: $255^{-258 .}$

Yamashita, Y., Fukuhara, M., Iwata, K., Sato, T., Araki, H., Ohmiya, K., Shimizu, N., Iwabuchi, K. 2014. Drip fertigation using dairy cow slurry processed by solid-liquid separation and aerobic digestion. (in Japanese text with English summary) J. Soc. Agric. Struc. Jpn. 45: 8-13. 